\title{
The effect of macroeconomic factors on credit risk in the banking system of Iran
}

\author{
Mohammad Khodaei Valahzaghard $^{\mathrm{a}^{*}}$, Maryam Kashefi ${ }^{\mathrm{b}}$, Amin Alikhani ${ }^{\mathrm{c}}$ and Seyed Esmaeil Hosseini ${ }^{\mathrm{d}}$
}

${ }^{a}$ Department of Accounting, Tehran North Branch, Islamic Azad University (IAU),Tehran, Iran

${ }^{b}$ Department of Management, Tehran North Branch, Islamic Azad University (IAU),Tehran, Iran

${ }^{c}$ Department of Economic, Tehran North Branch, Islamic Azad University (IAU),Tehran, Iran

${ }^{d}$ Department of Industrial Management, Qazvin Branch, Nokhbegan Street, Qazvin, Islamic Azad University (IAU),Tehran, Iran

A R T I C L E I N F O AB S T R A T

Article history:

Received December 18, 2011

Received in Revised form

February, 28, 2012

Accepted 16 April 2012

Available online

April 172012

Keywords:

Pending Claims

Credit Risk

Macroeconomic Factors

\begin{abstract}
These days, there are increasing changes on environmental and economic networks and different risks of various institutions affect the financial structure. Different institutions including financial and credit institutions are facing with the risk of lack of their timely obligations to make sure the repayment of the funds is granted. In this study, the effects of economic factors not affected by intentional behavior of customers are investigated.

Statistical study of the banking system includes all public and private banks. Statistical research community from 2005 to 2010 is considered. The cross-sectional data of the study and a combination of regression analysis is used. The regression analysis of combined data, fixed effects model based on the data is a cross-sectional fit. According to results of regression analysis, Pearson and Spearman's Correlation Coefficient, there is no significant relationship between the inflation rate, employment rate, unemployment rate, the dollar, the euro, with import growth of credit risk in the banking system in Iran. Therefore, based on probability theory, it can be stated that the credit risk in the banking system in Iran under the influence of variables is not mentioned. In addition, positive and significant relationship between stock index and credit risk in the banking system in Iran has increased by Weber in this index increases and reducing credit risk is reduced.
\end{abstract}

(C) 2012 Growing Science Ltd. All rights reserved.

\section{Introduction}

Today, banking is considered as one of the most important economic parts of each country. Banks via organizing and directing the receptions and payments, in fact, facilitate the affairs of commercial and business transactions and cause to advance the markets, increase and grow the economy. In fact, growth and advancement of economy without capital factor as one of production agents is impossible. It is not possible for all real and legal individuals during the stages of their activity to use personal monetary facilities and sources to supply the existing needs. The receptions and payments of economic units have scarcely coordinated with each other and to use the necessary facilities and

Corresponding author. Tel: +98-912-3443139

E-mail addresses: m_khodaei@iau-tnb.ac.ir (M. Khodaei Valahzaghard) 
sources, banks depend on credit and financial institutions (Gavin \& Haussman, 1996; Geambera , 2000; Enders, 2004; Kearns, 2004).

Granting banking facilities should be based on predictions of the principle sources of revenue expected to be realized in a certain period. Thus, different obstacles and problems including lack of accurate plan, economic instabilities, market stagnation, fluctuations of foreign exchange rate, liquidity and etc. cause that some of facility receivers ignore to repay their receivable funds and some of them by abusing the good intention of bank officials declined to repay the amount and naturally some of the facilities will be deferred (Pirouzfar, 2007; Safdari, 2008).

In Iran, the amount of claims of banking system was increasing in all parts since 2001 and it seems that the condition of macro economy could play an important role in credit status of banks and the quality of their claims. Arising crisis in financial system can lead to the exit of saving of depositors from banks. Therefore, if depositors feel there is a lack of reliance to the banking system and instable conditions and they find better way to keep their savings, they will begin to exit their deposits from banks. Moreover, whereas the banks granted the main part of the deposits of the customers as facilities, if those facilities do not repay on time, they will face to the sudden reduction of the sources and even in a pessimistic condition it may lead to the bankruptcy of banks. So, generally, it can be said that financial crisis attributes to a sudden and rapid shock or change in all or most of financial indexes include short-term rates, assets' price, change in managing behavior or function, bankruptcy and failure of financial institutions.

\section{Theoretical Framework Research}

Banks with proving the liquidity change and supervisory services have the most economic-financial mediators. Malfunction of banking system, for example, some of financial crisis of industrial and developing societies during past decades have been the most expensive. Therefore, it is necessary that the financial supervisors and central banks make most of their efforts to supervise the banking industry. Considering the main activity and operation of monetary and credit institutions, the "Credit Risk" due to the centrality of the volume of operations, especially its sensitivity, is mentioned as the most important risk.

Credit risk in monetary and credit institutions is important because resources used for allocation, in fact, are the monetary debt (lender) to shareholders, the banks and in the case of freezing or the (lack of fluid), will weaken the accreditation and payment of the monetary institution (lender). In particular, in balance sheets of financial institutions, credit facilities are considered as "timely demands" and individual deposits are considered as "instant debt". This means that claims (at determined duration) once impossible, but the payment of duties and liabilities (deposits), at the moment what is necessary, otherwise the money will be faced with bankruptcy. According to Article 412 of Commerce Law in Iran, the bankruptcy of businessman or a commercial company happens because of refusal of paying the funds which are obliged to him. Gavin and Haussmann (1996) performed an investigation for Latin America banking during the 1990s by investigating macroeconomic factors affecting the banking crisis.

According to their findings on domestic interest rates, expected inflation, GDP growth, balance of trade, domestic income growth, banking facilities and the exchange rates among the other variables were the most restrictive in lending capacity. According to the findings of several researchers like Demiurgic - Kunt Detragiache (1998) and Hardy and Pazabasioglu (1998), the Banking Failure of the banking system is the result of macroeconomic shocks. Gambera (2000), Bivariate VAR Model and America's commercial banks, regional and national economic variables to measure the effect on deferred loans can be used. Explanatory variables include unemployment rate, revenue of agricultural sector, number of structural permissions, annual production and sale of auto, as all of them except sale of Auto had meaningful effect when predicting the quality of the bank's assets. Baboucek and 
Jancar (2005), using monthly data for the Czech Banking Sector (1993 to 2005), considered the proportion of delayed loans to the whole of facilities as an indicator of the quality of loans. According to the fitted model, the strong relationship between quality of loans and some economic variables based on the immediate reaction was confirmed. Variables such as unemployment, consumer price index (CPI), inflation and credit risk shocks increase the real exchange rate. In addition, the stress-test considering the effect of such shocks to the economy of the Czech banking sector fragility measure was used. Acceleration of non-performance Loans, high unemployment and inflation tendencies were recognized as important warning indicators, to identify the credit portfolio.

According to other stress tests, stability of banking system, price stability and economic growth will depend. Filosa (2007) studied Italian banking system through a stress test estimates his findings indicates that failure rate of profit (profitability measures) is an indicator of the banking crisis. Kroszner et al. (2007) performed another study on banking crises and financial dependence and economic growth. In this article, they examined a mechanism that connect the banking crisis to the real sectors of the economy. There are other researches, which indicated that the credit risk of suffering a personal investment could affect on all investment risk and credit risk factors and their impact on investment and personal investment risk and credit risk factors can be divided into systematic investing. Aver (2009) studied the factors affecting the systematic credit risk, macroeconomic factors, economic policy, political change and political change as parts of the basic objectives. The inflation rate, employment rate, GDP growth, stock index and stock volatility and frequent fluctuations in the economy as macro-economic factors were considered.

Hashemi Nodehi (1998), examined the causes of past due receivables and deferred over the period 1986-1997 of an Iranian bank called Maskan. According to the survey, the variable interest rate and market interest rates for the different facilities, plus a penalty rate, interest rate than a money market, were approved nutrient claims.

All the studies mentioned above show the macroeconomic variables with earnings of banks procyclical. Heidary et al. (2010), in their studies, were seeking to find the effect of the behavior of macroeconomic factors and the effect of shocks on the amount deferred payments in terms of its banking from 2000 to 2008. According to research findings, the impact of variables such as non-oil GDP, inflation, liquidity, interest rate and price index of housing facilities, the demands on the banking system was confirmed. Hemmati and Mohebbi Nezad (2008) studied the changes in credit risk of all banks in the banking system in Iran from 2005 to 2010. This article assesses the impact of macroeconomic variables on banks' credit risk deals.

\section{Methodology of Research}

In this study, relation between variables of macro indexes of the economy with credit risk of banks with the use of Correlation Coefficient and Regression Tests is discussed. The study sample consisted of public and private Iranian banks, which were active from 2005 to 2010. In fact, the total population during the years of 2005 to 2010 , as a sample is examined.

\section{Analyze and Test Theories}

\subsection{Analysis and Description of Variables}

In this study, twelve macro-economic variables have been proposed, including inflation, employment rates, unemployment rates, interest rates, economic sectors, the growth of the dollar, the euro, stock index growth, import growth, export growth, GDP growth in current prices, the growth rate of GDP growth and stable prices is liquidity. 
This study examines the effect of macroeconomic factors on credit risk in country's banks. The credit belongs to the risk of sample data and data related to the country's macroeconomic indicators. The scope of this study is based on annual data from 2005 to 2010 and 19 banks have been sampled. Since the credit risk is calculated annually, number of observations is associated with the credit risk was 114 cases, but date relate to indexes of macro economy is for 6 years, as a result, data has six observations. Banks of country are classified based on their type of ownership and some of private banks were for a while with state ownership and other time with private ownership. Among the whole view of the possible ownership of banks, 63 private property and 51 were with public ownership. Information about the sample is shown in Table 1.

Table 1

Descriptive statistics of variables in the sample

\begin{tabular}{|c|c|c|c|c|c|c|c|c|}
\hline \multirow[t]{2}{*}{ Research Variable } & \multirow{2}{*}{ total } & \multirow{2}{*}{ Average } & \multirow{2}{*}{$\begin{array}{l}\text { Standard } \\
\text { deviation }\end{array}$} & \multirow{2}{*}{ Variance } & \multirow{2}{*}{ Skew } & \multirow{2}{*}{ Elongation } & \multicolumn{2}{|c|}{ Coefficient of variation } \\
\hline & & & & & & & Skew & Elongation \\
\hline Inflation rate & 6 & 0.149 & 0.059 & 0.003 & 1.461 & 1.301 & 1.728 & 0.747 \\
\hline Employment rate & 6 & 0.883 & 0.015 & 0.000 & -1.692 & 3.295 & -2.002 & 1.893 \\
\hline Unemployment rate & 6 & 0.117 & 0.015 & 0.000 & 1.692 & 3.295 & 2.002 & 1.893 \\
\hline Interest rate & 6 & 0.132 & 0.016 & 0.000 & 1.354 & 1.240 & 1.602 & 0.712 \\
\hline Growth in dollar & 6 & 0.027 & 0.040 & 0.002 & 0.058 & 0.190 & 0.069 & 0.109 \\
\hline Growth in Euro & 6 & 0.042 & 0.099 & 0.010 & -0.715 & -1.340 & -0.845 & -0.770 \\
\hline Stock index & 6 & 0.112 & 0.334 & 0.111 & 0.548 & -1.635 & 0.648 & -0.939 \\
\hline Import growth & 6 & 0.065 & 0.181 & 0.033 & -1.457 & 1.591 & -1.724 & 0.914 \\
\hline Export growth & 6 & 0.112 & 0.217 & 0.047 & -0.174 & -2.533 & -0.206 & -1.455 \\
\hline GDP growth in current prices & 6 & 0.148 & 0.100 & 0.010 & -0.771 & 1.747 & -0.912 & 1.004 \\
\hline GDP growth in fixed-price & 6 & 0.039 & 0.027 & 0.001 & 0.541 & -1.169 & 0.641 & -0.671 \\
\hline Growth of liquidity & 6 & 0.265 & 0.100 & 0.010 & 0.069 & -1.606 & 0.082 & -0.922 \\
\hline
\end{tabular}

In Table 1, there are other macroeconomic indicators including inflation, employment rates, unemployment rates, average interest rate of economic sectors, the growth of the dollar, the euro, stock index growth, growth indices of central tendency and dispersion of macroeconomic indicators. Credit risk of banks as the dependent variable is sampled. This variable with mean of 180.0 and standard deviation of 144. and variance of 0.021 has Chulgy and positive strain. As we can observe from the data, Chulgy deviation coefficient and the strain are severe. The dispersion and distribution of a normal distribution curve of the deviation is severe. Central tendency and dispersion characteristics are displayed in Table 2.

Table 2

Descriptive statistics of sample banks in credit risk

\begin{tabular}{lllllllll}
\hline Research Variable & total & Average & $\begin{array}{l}\text { Standard } \\
\text { deviation }\end{array}$ & Variance & Skew & Elongation & \multicolumn{2}{c}{ Coefficient of variation } \\
\cline { 7 - 11 } & & & Skew & Elongation \\
\hline Credit risk of banks & 114 & 0.180 & 0.021 & 0.021 & 1.893 & 5.514 & 8.358 & 12.273 \\
\hline
\end{tabular}

The regression analysis of combined data, fixed effects model based on the data is a cross-sectional fit. The use of regression analysis, a number of presumptive stem must be justified. The results of these tests are given in Table 3 and 4.

Table 3

Results of testing non-linearity between independent variables

\begin{tabular}{|c|c|c|c|c|c|c|c|c|c|c|c|c|}
\hline Variable & $\mathrm{CR}$ & ER & UER & MIR & USD & EUR & TEPIX & MR & XR & GDCR & GDCO & LQ \\
\hline CPI & 1 & .525 & -.525 & -.557 & .365 & -.364 & -.477 & .442 & -.014 & .477 & .053 & -.451 \\
\hline ER & .525 & 1 & -1.000 & -.106 & -.245 & -.260 & -.669 & .947 & .584 & .465 & .607 & .408 \\
\hline UER & -.525 & -1.000 & 1 & .106 & .245 & .260 & .669 & -.947 & -.584 & -.465 & -.607 & -.408 \\
\hline MIR & -.557 & -.106 & .106 & 1 & .034 & -.306 & -.420 & .114 & .569 & .141 & .169 & .568 \\
\hline USD & .365 & -.245 & .245 & .034 & 1 & -.760 & -.174 & -.161 & -.459 & -.219 & -.753 & -.638 \\
\hline EUR & -.364 & -.260 & .260 & -.306 & -.760 & 1 & .584 & -.307 & -.025 & .012 & .387 & .257 \\
\hline TEPIX & -.477 & -.669 & .669 & -.420 & -.174 & .584 & 1 & -.788 & -.755 & -.742 & -.480 & -.331 \\
\hline MR & .442 & .947 & -.947 & .114 & -.161 & -.307 & -.788 & 1 & .700 & .528 & .639 & .551 \\
\hline XR & -.014 & .584 & -.584 & .569 & -.459 & -.025 & -.755 & .700 & 1 & .755 & .870 & .790 \\
\hline GDCR & .477 & .465 & -.465 & .141 & -.219 & .012 & -.742 & .528 & .755 & 1 & .742 & .279 \\
\hline GDCO & .053 & .607 & -.607 & .169 & -.753 & .387 & -.480 & .639 & .870 & .742 & 1 & .754 \\
\hline LQ & -.451 & .408 & -.408 & .568 & -.638 & .257 & -.331 & .551 & .790 & .279 & .754 & 1 \\
\hline
\end{tabular}


Table 4

Results of tests of variables' distribution, examining the intercept, Hasmn, linear relationship between variables, the distribution of residual and Durbin \& Watson

\begin{tabular}{|c|c|c|c|c|c|c|c|c|c|c|c|c|c|c|}
\hline & & $\mathrm{CR}$ & CPI & ER & UER & MIR & USD & EUR & TEPIX & MR & $\mathrm{XR}$ & GDCR & GDCO & LQ \\
\hline \multirow{3}{*}{ 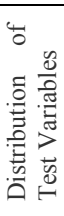 } & $\begin{array}{l}\text { Colmogr } \\
\text { ov- } \\
\text { Smirnov }\end{array}$ & $\begin{array}{l}.136 \\
.000\end{array}$ & $\begin{array}{l}.343 \\
.000\end{array}$ & $\begin{array}{l}.277 \\
.000\end{array}$ & $\begin{array}{l}.277 \\
.000\end{array}$ & $\begin{array}{l}.286 \\
.000\end{array}$ & $\begin{array}{l}.164 \\
.000\end{array}$ & $\begin{array}{l}.290 \\
.000\end{array}$ & $\begin{array}{l}.259 \\
.000\end{array}$ & $\begin{array}{l}.296 \\
.000\end{array}$ & $\begin{array}{l}.257 \\
.000\end{array}$ & $\begin{array}{l}.218 \\
.000\end{array}$ & $\begin{array}{l}.245 \\
.000\end{array}$ & $\begin{array}{l}.207 \\
.000\end{array}$ \\
\hline & $\begin{array}{l}\text { Shapiro- } \\
\text { Walk }\end{array}$ & $\begin{array}{l}.845 \\
.000\end{array}$ & $\begin{array}{l}.735 \\
.000\end{array}$ & $\begin{array}{l}.752 \\
.000\end{array}$ & $\begin{array}{l}.752 \\
.000\end{array}$ & $\begin{array}{l}.745 \\
.000\end{array}$ & $\begin{array}{l}.900 \\
.000\end{array}$ & $\begin{array}{l}.816 \\
.000\end{array}$ & $\begin{array}{l}.809 \\
.000\end{array}$ & $\begin{array}{l}.765 \\
.000\end{array}$ & $\begin{array}{l}.797 \\
.000\end{array}$ & $\begin{array}{l}.850 \\
.000\end{array}$ & $\begin{array}{l}.863 \\
.000\end{array}$ & $\begin{array}{l}.869 \\
.000\end{array}$ \\
\hline & $\begin{array}{l}\text { Jarque-- } \\
\text { Bera }\end{array}$ & $\begin{array}{l}193.996 \\
.000\end{array}$ & $\begin{array}{l}22.675 \\
.000\end{array}$ & $\begin{array}{l}27.663 \\
.000\end{array}$ & $\begin{array}{l}20.899 \\
.000\end{array}$ & $\begin{array}{l}19.457 \\
.000\end{array}$ & $\begin{array}{l}3.321 \\
.190\end{array}$ & $\begin{array}{l}13.405 \\
.001\end{array}$ & $\begin{array}{l}12.589 \\
.001\end{array}$ & $\begin{array}{l}21.981 \\
.000\end{array}$ & $\begin{array}{l}14.452 \\
.000\end{array}$ & $\begin{array}{l}6.180 \\
.045\end{array}$ & $\begin{array}{l}11.128 \\
.003\end{array}$ & $\begin{array}{l}9.461 \\
.008\end{array}$ \\
\hline \multicolumn{2}{|c|}{ Chow } & - & $\begin{array}{l}6.442 \\
.000\end{array}$ & $\begin{array}{l}6.592 \\
.000\end{array}$ & $\begin{array}{l}6.445 \\
.000\end{array}$ & $\begin{array}{l}7.348 \\
.000\end{array}$ & $\begin{array}{l}6.439 \\
.000\end{array}$ & $\begin{array}{l}6.515 \\
.000\end{array}$ & $\begin{array}{l}7.208 \\
.000\end{array}$ & $\begin{array}{l}6.649 \\
.000\end{array}$ & $\begin{array}{l}7.557 \\
.000\end{array}$ & $\begin{array}{l}6.981 \\
.000\end{array}$ & $\begin{array}{l}6.890 \\
.000\end{array}$ & $\begin{array}{l}6.854 \\
.000\end{array}$ \\
\hline \multicolumn{2}{|c|}{ Housman } & - & $\begin{array}{l}0.000 \\
1.000\end{array}$ & $\begin{array}{l}0.000 \\
1.000\end{array}$ & $\begin{array}{l}0.000 \\
1.000\end{array}$ & $\begin{array}{l}0.000 \\
1.000\end{array}$ & $\begin{array}{l}0.000 \\
1.000\end{array}$ & $\begin{array}{l}0.000 \\
1.000\end{array}$ & $\begin{array}{l}0.000 \\
1.000\end{array}$ & $\begin{array}{l}0.000 \\
1.000\end{array}$ & $\begin{array}{l}0.000 \\
1.000\end{array}$ & $\begin{array}{l}0.000 \\
1.000\end{array}$ & $\begin{array}{l}0.000 \\
1.000\end{array}$ & $\begin{array}{l}0.000 \\
1.000\end{array}$ \\
\hline \multicolumn{2}{|c|}{$\begin{array}{l}\text { Linear } \\
\text { relationship } \\
\text { between } \\
\text { dependent and } \\
\text { independent } \\
\text { variables }\end{array}$} & - & $\begin{array}{l}0.484 \\
.488\end{array}$ & $\begin{array}{l}2.681 \\
.104\end{array}$ & $\begin{array}{l}0.526 \\
.469\end{array}$ & $\begin{array}{l}13.767 \\
.000\end{array}$ & $\begin{array}{l}0.434 \\
.510\end{array}$ & $\begin{array}{l}1.552 \\
.215\end{array}$ & $\begin{array}{l}11.720 \\
.000\end{array}$ & $\begin{array}{l}3.517 \\
.0633\end{array}$ & $\begin{array}{l}16.836 \\
.000\end{array}$ & $\begin{array}{l}8.391 \\
.004\end{array}$ & $\begin{array}{l}7.049 \\
.009\end{array}$ & $\begin{array}{l}6.528 \\
.0119\end{array}$ \\
\hline \multicolumn{2}{|c|}{$\begin{array}{l}\text { Distribution of } \\
\text { waste }\end{array}$} & - & $\begin{array}{l}202.94 \\
9 \\
.000\end{array}$ & $\begin{array}{l}218.14 \\
7 \\
.000\end{array}$ & $\begin{array}{l}204.82 \\
9 \\
.000\end{array}$ & $\begin{array}{l}245.67 \\
0 \\
.000\end{array}$ & $\begin{array}{l}205.08 \\
1 \\
.000\end{array}$ & $\begin{array}{l}185.71 \\
4 \\
.000\end{array}$ & $\begin{array}{l}220.74 \\
1 \\
.000\end{array}$ & $\begin{array}{l}231.40 \\
3 \\
.000\end{array}$ & $\begin{array}{l}284.71 \\
6 \\
.000\end{array}$ & $\begin{array}{l}202.18 \\
0 \\
.000\end{array}$ & $\begin{array}{l}253.04 \\
8 \\
.000\end{array}$ & $\begin{array}{l}284.852 \\
6 \\
.000000\end{array}$ \\
\hline \multicolumn{2}{|c|}{$\begin{array}{l}\text { Durbin } \\
\text { Watson }\end{array}$} & - & $\begin{array}{l}1.521 \\
1.5\end{array}$ & $\begin{array}{l}1.556 \\
1.5\end{array}$ & $\begin{array}{l}1.525 \\
1.5\end{array}$ & $\begin{array}{l}1.659 \\
1.5\end{array}$ & $\begin{array}{l}1.521 \\
1.5\end{array}$ & $\begin{array}{l}1.509 \\
1.5\end{array}$ & $\begin{array}{l}1.643 \\
1.5\end{array}$ & $\begin{array}{l}1.599 \\
1.5\end{array}$ & $\begin{array}{l}1.653 \\
1.5\end{array}$ & $\begin{array}{l}1.551 \\
1.5\end{array}$ & $\begin{array}{l}1.640 \\
1.5\end{array}$ & $\begin{array}{l}1.73522 \\
4 \\
1.5\end{array}$ \\
\hline
\end{tabular}

\subsection{Regression test and hypothesis}

In this subsection, the theoretical model and hypotheses of research with regard to collinear of more variables are performed separately and the effect of each of macroeconomic index on credit risk is discussed. Table 5 shows details of our tests for regression analysis, Pearson and Spearman tests. The first row and second row of each test show coefficient and significance in $95 \%$ level of assurance, respectively.

Table 5

Results of regression analysis and correlation coefficients between independent variables and credit risk

\begin{tabular}{lllllllllllll}
\hline \multicolumn{1}{l}{ Independent variables } & \multicolumn{1}{l}{ CPI } & ER & UER & MIR & USD & EUR & TEPIX & MR & XR & GDCR & GDCO & LQ \\
\hline \multirow{2}{*}{ Regression } & 0.161 & 1.009 & 0.126 & 0.489 & 0.175 & 0.174 & 0.168 & 0.187 & 0.201 & 0.225 & 0.220 & 0.251 \\
& 0.000 & 0.048 & 0.110 & 0.000 & 0.000 & 0.000 & 0.000 & 0.000 & 0.000 & 0.000 & 0.000 & 0.000 \\
$\mathrm{R}^{2}$ & 0.004 & 0.023 & 0.004 & 0.109 & 0.003 & 0.013 & 0.094 & 0.03 & 0.130 & 0.069 & 0.059 & 0.055 \\
\hline Pearson & 0.037 & -0.089 & 0.089 & -0.239 & 0.047 & 0.089 & 0.225 & -0.129 & -0.261 & -0.192 & -0.167 & -0.169 \\
& 0.696 & 0.344 & 0.344 & 0.011 & 0.621 & 0.347 & 0.016 & 0.170 & 0.005 & 0.040 & 0.075 & 0.072 \\
\hline Spearman & 0.164 & -.109 & 0.109 & -0.273 & 0.126 & -0.025 & 0.299 & -0.117 & -0.382 & -0.242 & -0.277 & -0.315 \\
& .0 .081 & 0.248 & 0.248 & 0.003 & 0.181 & 0.793 & 0.001 & 0.216 & 0.000 & 0.009 & 0.003 & 0.001 \\
\hline
\end{tabular}

Table 6 summarizes details of our finding on regression analysis. As we can observe from the results of Table 6, there are 12 hypothesis associated with the regression analysis. The results indicate that the null hypothesis of having meaningful relationship between the dependent variable (credit risk) and independent variable are rejected only for hypothesis four and seven and in other cases, we do not have enough evidence to reject the null hypothesis based on all regression analysis, Pearson and Spearman correlation tests when the significance level is 0.05 . We have also performed a regression where the dependent variable is credit risk and independent variables are interest rate and growth in stock index as follows,

$y_{i}=\beta_{0 i}+\beta_{1 i} x_{1 i}+\beta_{2 i} x_{2 i}+\varepsilon_{i}$,

where $y_{i}$ represents the credit risk as dependent variable, $x_{1}$ is interest rate and $x_{2}$ is growth stock index. Table 7 shows details of the statistical observations for the regression analysis. 


\section{Table 6}

Results of regression testing research hypotheses, Pearson and Spearman coefficients

\begin{tabular}{|c|c|c|c|c|c|c|c|c|}
\hline \multirow[t]{2}{*}{ Hypothesis } & \multirow[t]{2}{*}{ Independent variable } & \multicolumn{2}{|c|}{$\begin{array}{l}\text { Regression } \\
\text { analysis }\end{array}$} & \multicolumn{2}{|c|}{$\begin{array}{l}\text { Pearson } \\
\text { correlation }\end{array}$} & \multicolumn{2}{|c|}{$\begin{array}{l}\text { Spearman } \\
\text { correlation }\end{array}$} & \multirow[t]{2}{*}{ Result } \\
\hline & & $\beta=0$ & $\beta \neq 0$ & $\beta=0$ & $\beta \neq 0$ & $\beta=0$ & $\beta \neq 0$ & \\
\hline First & Inflation rate & $\sqrt{ }$ & $\times$ & $\sqrt{ }$ & $\times$ & $\sqrt{ }$ & $\times$ & Not significant \\
\hline second & Employment rate & $\sqrt{ }$ & $x$ & $\sqrt{ }$ & $x$ & $\sqrt{ }$ & $x$ & Not significant \\
\hline Third & Unemployment rate & $\sqrt{ }$ & $\times$ & $\sqrt{ }$ & $x$ & $\sqrt{ }$ & $x$ & Not significant \\
\hline Fourth & Interest rate & $\sqrt{ }$ & $\times$ & $\sqrt{ }$ & $x$ & $\sqrt{ }$ & $\times$ & significant and negative \\
\hline Fifth & Growth in dollar & $x$ & $\sqrt{ }$ & $x$ & $\sqrt{ }$ & $x$ & $\sqrt{ }$ & Not significant \\
\hline sixth & Growth in Euro & $\sqrt{ }$ & $x$ & $\sqrt{ }$ & $x$ & $\sqrt{ }$ & $x$ & Not significant \\
\hline Seventh & Stock index & $\sqrt{ }$ & $x$ & $\sqrt{ }$ & $x$ & $\sqrt{ }$ & $\times$ & significant and positive \\
\hline eighth & Import growth & $\times$ & $\sqrt{ }$ & $\times$ & $\sqrt{ }$ & $x$ & $\sqrt{ }$ & Not significant \\
\hline Ninth & Export growth & $\sqrt{ }$ & $\times$ & $\sqrt{ }$ & $\times$ & $\sqrt{ }$ & $\times$ & significant and negative \\
\hline Tenth & GDP growth in current prices & $x$ & $\sqrt{ }$ & $x$ & $\sqrt{ }$ & $x$ & $\sqrt{ }$ & significant and negative \\
\hline Eleventh & GDP growth in fixed-price & $x$ & $\sqrt{ }$ & $x$ & $\sqrt{ }$ & $x$ & $\sqrt{ }$ & significant and negative \\
\hline Twelfth & Growth of liquidity & $\times$ & $\sqrt{ }$ & $\sqrt{ }$ & $\times$ & $\times$ & $\sqrt{ }$ & significant and negative \\
\hline
\end{tabular}

\section{Table 7}

Results of regression analysis to test the effect of interest rates, economic sectors and stock growth index on credit risk

\begin{tabular}{|c|c|c|c|c|c|c|c|}
\hline \multicolumn{4}{|c|}{ Variable name } & \multirow{2}{*}{$\begin{array}{l}\text { Coefficient } \\
0.400979\end{array}$} & \multirow{2}{*}{$\begin{array}{l}\text { Standard error } \\
0.095075\end{array}$} & \multirow{2}{*}{$\begin{array}{l}\text { Statistics t } \\
4.217497\end{array}$} & \multirow{2}{*}{$\begin{array}{l}\text { Significant level } \\
0.0001\end{array}$} \\
\hline$\beta_{0}$ & $\mathrm{C}$ & \multicolumn{2}{|c|}{ Constant factor } & & & & \\
\hline$\beta_{1}$ & S1 & \multicolumn{2}{|c|}{ Interest rate } & -1.735726 & 0.684346 & -2.536327 & 0.0126 \\
\hline$\beta_{2}$ & $\mathrm{~S} 2$ & \multicolumn{2}{|c|}{ Growth stock index } & 0.070042 & 0.032858 & 2.131669 & 0.0352 \\
\hline \multicolumn{2}{|c|}{$\mathrm{R}^{2}$} & $\mathrm{~F}$ & S.E & D-W & MDV & S.D.DV & SSR \\
\hline \multicolumn{2}{|c|}{0.145043} & 9.415533 & 0.096997 & 1.699357 & 0.065280 & 0.103970 & 1.044331 \\
\hline
\end{tabular}

As we can observe from the results of regression analysis, all t-students are meaningful and the significance level is less than 0.05. Durbin-Watson ration is on acceptable level, which means $E\left(u_{i}, u_{j}\right)=0$. According to the results, as interest rate increases, credit risk decreases and an increase on growth of stock market will increase credit risk. Of course, $\mathrm{R}^{2}$ is 0.14 , which means these two variable do not represent significant amount of factors influence the credit risk.

We have performed another regression analysis between credit risk as dependent variable and ownership status of banks as independent variable and Table 8 shows details of the results.

\section{Table 8}

Results of regression analysis to test the effect of ownership on bank credit risk

\begin{tabular}{|c|c|c|c|c|c|c|c|}
\hline \multicolumn{4}{|c|}{ Variable name } & Coefficient & Standard error & Statistics $\mathrm{t}$ & Significant level \\
\hline$\beta_{0}$ & $\mathrm{C}$ & \multicolumn{2}{|c|}{ Constant factor } & 0.173194 & 0.029374 & 5.896256 & 0.0000 \\
\hline$\beta_{1}$ & S1 & \multicolumn{2}{|c|}{ Public and private banks } & 0.015801 & 0.036458 & 0.433409 & 0.6656 \\
\hline \multicolumn{2}{|l|}{$\mathrm{R}^{2}$} & $\mathrm{~F}$ & S.E & $\mathrm{D}-\mathrm{W}$ & MDV & S.D.DV & SSR \\
\hline \multicolumn{2}{|c|}{0.001655} & 0.185681 & 0.106123 & 1.482800 & 0.072919 & 0.105740 & 1.261365 \\
\hline
\end{tabular}

As we can observe from the results of Table 8, there is not a meaningful relationship between credit risk and ownership of banks. We have also performed a regression analysis to see whether governmental banks maintain more risk than private ones Table 9 shows details of our test when the significance level is 0.05 . 
Table 9

Comparison of average credit risk in two independent test results

\begin{tabular}{|c|c|c|c|c|c|c|c|}
\hline \multirow{2}{*}{ Private Bank } & \multirow{2}{*}{ State bank } & \multicolumn{2}{|c|}{ Variance compared } & \multicolumn{4}{|c|}{ Average compared } \\
\hline & & $\begin{array}{l}\mathrm{F} \\
\text { statistic }\end{array}$ & $\mathrm{P}$ & T statistic & Degrees of freedom & $\mathrm{P}$ & The mean difference \\
\hline 0.15449205 & 0.2124796 & 0.000 & 0.985 & -2.169 & 112 & 0.032 & -0.057987504 \\
\hline
\end{tabular}

The results of Table 9 shows that governmental banks preserves higher credit risk compared with private ones when the significance level is 0.05 .

\section{Conclusion}

In this paper, we have performed an empirical study to investigate the effects of economic factors, which were not affected by intentional behavior of customers based on the data collected from all public and private banks and statistical research community from 2005 to 2010. The cross-sectional data of the study and a combination of regression analysis were used. The regression analysis of combined data, fixed effects model based on the data was a cross-sectional fit. According to test results of regression analysis, Pearson and Spearman's Correlation Coefficient, a significant relationship between the inflation rate, employment rate, unemployment rate, the dollar, the euro, with import growth of credit risk in the banking system in Iran were not observed. Therefore, based on probability theory, it can be stated that the credit risk in the banking system in Iran under the influence of variables is not mentioned. In addition, positive and significant relationship between stock index and credit risk in the banking system in Iran has increased by Weber in this index increases and reducing credit risk is reduced.

\section{Acknowledgment}

The authors would like to thank the people who helped us accomplished this paper. We are also grateful for construction comments on earlier version of this work.

\section{References}

Aver, B. (2009). An empirical analysis of credit risk factors of the Slovenian banking system. Managing Global Transitions, 6(3), 317-334.

Baboucek, I., \& Jancer, M. (2005). Effects of Macroeconomic Shock to the Quality of the Aggregate Loan Portfolio.Czech National Bank, Working Paper Series, 1,1-62

Bikker, J.A., \& Metzemakers, P.A.J. (2002). Bank provisioning behaviour and procyclicality. Research Series Supervision, 50, 1-21.

Demirgǖç-Kunt, A., \& Detragiache, E. (1998).The determinants of banking crises in developing and developed countries. IMF Staff Papers, 45,(1), 81-109.

Enders, W. (2004). Applied Econometric Time Series.2 ${ }^{\text {nd }}$ (ed.). New Jersey: John Wiley \& Sons.

Filosa, R. (2007). Stress Testing of Stability of the Italian Banking System: a VAR approach. Heterogeneity and Monetary Policy,0703, 1-46.

Gavin, M., \& Haussman, R. (1996).The Roots of Banking Crises: The Macroeconomic Context. Inter-American Bank, Working Paper, 318,1-20.

Geambera, M. (2000).Simple forecasts of bank loan in the business cycle. Emerging Issues Series, 3 , $1-27$.

Hashemi Nodehi, M.M. (1998). Causes of past due receivables and deferred claims of Maskan Bank.

Hemmati, A., Mohebbi Nejad, S. (2008). Evaluation the effect of Macroeconomic factors on credit risk for banks. Economic Journal, 6, 33-59.

Markowitz, H.M. (1952). Portfolio selection. The Journal of Finance, 7(1), 77-91. 
1754

Kearns, A. (2004). Loan losses and the macroeconomy: A framework for stress testing credit institution's financial well-being. Financial Stability Report, 29,111-121.

Kroszner, R. S., Luc, L., \& Klingebiel, D., (2007). Banking crises, financial dependence and growth. Journal of Financial Economics, 87, 187-228.

Pirouzfar, A. (2007). Claims pending state banks. Bank and Economics, 87, 46-49.

Safdari, N. (2008). Improving the banking system to cover the risks associated with pending claims. New Economy, 122, 66-70. 